\title{
Eksperimentasi Model PBL dan Model GDL Terhadap Kemampuan Pemecahan Masalah Matematis Ditinjau dari Kemandirian Belajar
}

\author{
Evi Yuliasari \\ Program Studi Pendidikan Matematika, Universitas Negeri Jakarta \\ Email: vineezz.brbs89@gmail.com
}

\begin{abstract}
Abstrak
Penelitian ini bertujuan untuk mengetahui eksperimentasi model pembelajaran Problem Based Learning (PBL) dan model pembelajaran Guided Discovery Learning (GDL) terhadap kemampuan pemecahan masalah matematis siswa ditinjau dari kemandirian belajar siswa. Metode yang digunakan dalam penelitian ini adalah quasi eksperimen. Teknik pengambilan sampel dengan multistage random sampling. Teknik pengumpulan data yaitu tes kemampuan pemecahan masalah dan angket kemandirian belajar. Pengujian hipotesis menggunakan teknik anava dua jalur dengan taraf signifikansi 5\%. Sebelum uji hipotesis, dilakukan uji prasyarat yaitu uji normalitas dengan uji kolmogorov-smirnov dan uji homogenitas dengan uji Levene. Hasil penelitian menunjukkan bahwa (1) kemampuan pemecahan masalah matematis siswa dengan pembelajaran model PBL lebih tinggi daripada diberi kemampuan pemecahan masalah matematis siswa yang dengan pembelajaran model GDL, (2) pengaruh interaksi antara model pembelajaran dan kemandirian belajar terhadap kemampuan pemecahan masalah matematis siswa, (3) kemampuan pemecahan masalah matematis siswa dengan pembelajaran model PBL lebih tinggi daripada kemampuan pemecahan masalah matematis siswa dengan pembelajaran model GDL pada kelompok siswa yang memiliki kemandirian belajar tinggi, (4) tidak terdapat perbedaan kemampuan pemecahan masalah matematis siswa antara siswa dengan pembelajaran model PBL dan dengan pembelajaran model GDL pada kelompok siswa yang memiliki kemandirian belajar rendah.
\end{abstract}

Kata Kunci : PBL; GDL; Kemampuaan pemecahan masalah; Kemandirian belajar

\section{The Effect Of PBL and GDL Model to Mathematical Problem Solving Ability Viewed From Self Regulated Learning}

\begin{abstract}
This Research aims to determine the effect of Problem-Based Learning (PBL) model and Guided Discovery Learning(GDL) model of learning ability of students' mathematical problem solving in terms of self regulated learning. This was a quasi experiment research. The sampling technique is multistage random sampling. The data collection technique is mathematical problem solving ability test on essay form and questionnaire self regulated learning of student. Hypothesis testing using two-way anava technique with 5\% significance level. The conclusion of this research shows that (1) the mathematical problem solving ability of students who are treated with PBL model is higher than the amathematical problem solving ability of students who are treated with GDL model, (2) there is interaction effect between learning model and self regulated learning to mathematical problem solving abilities of student , (3) mathematical problem solving abilities treated by PBL model is higher than mathematical problem solving ability given GDL model in groups of students who have high self regulated learning, (4) there is no difference in mathematical problem solving ability among students who are given Treatment of PBL models and treated with GDL models in groups of students who have low self regulated learning.
\end{abstract}

Keywords : PBL; GDL; Problem Solving Ability; Self Regulated Learning 


\section{PENDAHULUAN}

Pendidikan adalah investasi sumber daya manusia jangka panjang yang mempunyai nilai strategis bagi kelangsungan peradaban manusia di dunia. Begitu juga Indonesia menempatkan pendidikan sebagai suatu yang penting. Berbagai upaya dilakukan oleh pemerintah seperti penyempurnaan kurikulum, peningkatan kompetensi guru, penyediaan sarana dan prasarana pendidikan, maupun beragam usaha peningkatan mutu pendidikan yang diharapkan. Semua itu bertujuan agar mutu pendidikan Indonesia semakin baik dan tidak tertinggal oleh negara lain.

Tujuan pembelajaran matematika adalah untuk mengembangkan kemampuan pemecahan masalah matematika yang kompleks (Abidin, 2015). Namun pada kenyataannya kemampuan pemecahan masalah di Indonesia masih rendah. Berdasarkan hasil penilaian internasional TIMSS dan PISA. Berdasarkan data, TIMSS tahun 2015, Indonesia berada pada peringkat ke-45 dari 50 peserta dengan rata-rata skor 397. Selain itu menurut data PISA, pada tahun 2012 Indonesia berada pada peringkat ke-64 dari 65 negara, dengan nilai rata-rata 375. Data terbaru PISA 2015 menunjukkan, Indonesia berada pada peringkat ke-61 dari 69 negara dengan skor 386. Refleksi dari hasil TIMSS dan PISA adalah kurang terlatihnya Indonesia dalam menyelesaikan soal-soal dengan karakteristik yang sama dengan soal-soal pada TIMSS dan PISA

Studi pendahuluan kemampuan pemecahan masalah matematis yang dilakukan oleh (Hanifah, 2015) melibatkan 36 siswa kelas VII pada salah satu SMP Negeri di Kabupaten Karawang melaporkan bahwa kemampuan pemecahan masalah matematis siswa masih belum maksimal. Penelitian
(Yonandi, 2011) melibatkan 244 siswa kelas XI dari dua SMA negeri dari level sedang dan tinggi di Tasikmalaya. Hasil studi pendahuluan mengungkapkan kemampuan pemecahan masalah matematis pada tiap level sekolah tidak berbeda secara signifikan dan semuanya tergolong sangat rendah.

Salah satu upaya untuk meningkatkan kemampuan pemecahan masalah adalah pendidik perlu memilih model pembelajaran yang sesuai dengan materi yang dipelajari sehingga kemampuan pemecahan masalah dapat meningkat. Salah satu model pembelajaran yang dapat menumbuhkan kemampuan pemecahan masalah adalah model Problem Based Learning (Arends, 2008) dan model Guided Discovery Learning (Illahi, 2012).

Problem Based Learning merupakan suatu model yang dimulai dengan menghadapkan siswa pada masalah keseharian yang nyata atau masalah yang disimulasikan sehingga siswa diharapkan menjadi terampil dalam memecahkan masalah. Padmavathy dan (Padmavathy \& Mareesh.K, 2013), dalam penelitiannya menyatakan bahwa dengan mengadopsi metode Problem Based Learning siswa menjadi berpikir kreatif, strategi pembelajaran berbasis masalah memiliki efek pada pengetahuan yang memberikan peluang yang lebih besar bagi siswa untuk belajar dengan keterlibatan yang lebih banyak dan meningkatkan par-tisipasi aktif siswa, motivasi dan hubungan antara siswa.

Model lain yang dapat meningkatkan kemampuan pemecahan masalah adalah Guided Discovery Learning (Illahi, 2012). Model pembelajaran Guided Discovery Learning menggunakan pendekatan induktif, atau penyelidikan untuk belajar, strategi ini menyajikan masalah untuk diselesaikan melalui percobaan dan kesalahan (trial and 
error) sehingga memberikan kesempatan yang besar pada diri siswa untuk membangun pengetahuannya dalam menemukan solusi dari suatu masalah. Casad, State, Jawaharlal, \& State (2012) mengatakan Guided Discovery adalah sebuah proses di mana siswa didorong untuk menemukan kembali sebagai upaya memberikan pengetahuan melalui penemuan sendiri dan penemuan orang lain. Pembelajaran nyata terjadi ketika siswa masuk ke dalam situasi otentik dan diperbolehkan untuk mencari tahu solusi sehingga mereka mengalami "aha!" di saat mereka menemukan pengetahuan sendiri.

Selain model pembelajaran, masih banyak hal yang mempengaruhi hasil kemampuan pemecahan masalah, salah satunya adalah kemandirian belajar siswa (self regulated learning). Kemandirian belajar adalah suatu keadaan dimana seseorang memiliki hasrat bersaing untuk maju demi kebaikan dirinya, mampu mengambil keputusan, berinisiatif untuk mengatasi masalah yang dihadapi, memiliki kepercayaan diri dalam mengerjakan tugas-tugas, dan bertanggung jawab atas apa yang dilakukannya (E. Nurhayati, 2011). Perels, Dignath, \& Schmitz, (2009) dalam penelitiannya mengatakan bahwa siswa yang memiliki kemandirian belajar yang baik mempunyai efek pada prestasi matematika yang baik pula. Menurut Metallidou \& Vlachou, (2010) dalam penelitian mengatakan bahwa siswa yang mempunyai kemandirian belajar akan dapat menyelesaikan tugas-tugas yang diberikan dengan baik.

Kedua model pembelajaran Problem Based Learning dan Guided Discovery Learning dapat meningkatkan kemampuan pemecahan masalah matematis. Peneliti tertarik untuk melihat efektivitas kedua model tersebut jika ditinjau dari kemandirian belajar. Apakah dengan kemandirian belajar yang berbeda antara siswa satu dengan siswa lainnya dapat memberikan pengaruh yang berbeda jika model pembelajaran Problem Based Learning dan Guided Discovery Learning diterapkan. Berdasar pada paparan diatas maka akan dilakukan penelitian tentang "Eksperimentasi Model Pembelajaran Problem Based Learning dan Model Pembelajaran Guided Discovery Learning Terhadap Kemampuan Pemecahan Masalah Matematis Ditinjau dari Kemandirian Belajar Siswa."

\section{METODE}

Metode penelitian yang digunakan adalah Quasi Eksperimen. Desain penelitian yang dipakai dalam penelitian ini adalah Postest Only Control Design. Penelitian ini menggunakan model eksperimen I dengan desain faktorial $2 \times 2$ treatment by level. Populasi target dalam penelitian ini adalah seluruh siswa kelas VIII Sekolah Menengah Pertama di Kecamatan Pasar Rebo yang terdaftar pada tahun ajaran 2016/2017. Populasi terjangkau diambil dengan menggunakan multistage sampling sehingga mentetapkan SMP Negeri 184 Jakarta secara simple random sampling untuk dijadikan tempat penelitian dan kelas VIII sebagai sampel sesuai dengan tujuan penelitian.

Dalam pengambilan sampel dilakukan dengan menguji nilai UAS semester gasal dengan menggunakan uji normalitas, uji homogenitas dan uji kesamaan rata-rata maka yang akan menjadi sampel penelitian adalah kelas VIII 3, VIII 4, VIII 5, dan VIII 6 dengan kelas VIII 3 dan VIII 6 sebagai kelas eksperimen I yaitu menggunakan model Problem Based Learning sedangkan kelas VIII 4 dan VIII 5 sebagai kelas eksperimen II 
yang menggunakan model Guided Discovery Learning. Selanjutnya masing-masing kelas eksperimen dibagi menjadi dua yaitu siswa dengan kemandirian belajar tinggi dan siswa dengan kemandirian belajar rendah. Untuk membagi siswa menjadi kate-gori kemandirian belajar tinggi dan keman-dirian belajar rendah dengan cara simple random sampling dengan cara menentukan $33 \%\left(M_{T}=M_{R}=33 \%\right)$ dimana angka cukup kontras dan reliable (Naga, 1992).

Pengumpulan data yang digunakan dalam penelitian ini adalah dengan menggunakan instrumen tes kemampuan pemecahan masalah matematis untuk variabel terikat dan instrumen angket kemandirian belajar untuk variabel moderator. Teknik analisis data dalam penelitian ini adalah meliputi uji normalitas uji dengan menggunakan Kolmogorov Smirnov dan uji homogenitas dengan menggunakan uji levene yang merupakan uji prasayarat analisis. Uji hipotesis yang dilakukan dalam penelitian ini menggunakan teknik analisis varians (ANAVA) dua jalur. Setelah dilakukan anava dua jalur dan hasil dari analisis data menyatakan bahwa ada nteraksi antara model pembelajaran dan kemandirian belajar secara signifikan maka akan dilanjutkan dengan uji-t.

\section{HASIL DAN PEMBAHASAN}

\section{HASIL}

Rerata skor kemampuan pemecahan masalah matematis siswa pada masing-masing kategori dapat dilihat pada Tabel 1 berikut:

Tabel 1. Rangkuman Rata-rata Skor Kemampuan Pemecahan Masalah Matematis Siswa

\begin{tabular}{cccc}
\hline Model & \multicolumn{2}{c}{$\begin{array}{c}\text { Kemandirian } \\
\text { Belajar }\end{array}$} & \multirow{2}{*}{$\begin{array}{c}\text { Rataan } \\
\text { Marginal }\end{array}$} \\
\cline { 2 - 3 } & Tinggi & Rendah & \\
\hline PBL & 5,65 & 3,79 & 4,73
\end{tabular}

GDL

4,19

3,86

4,03

Prosedur uji hipotesis dalam penelitian ini menggunakan Anova Dua Jalur. Hasil perhitungan dapat dilihat dalam Tabel 2 berikut:

Tabel 2. Hasil Uji Anava Dua Jalur

\begin{tabular}{lcc} 
Dependent Variable: Nilai_KPM & & \\
\hline \multicolumn{1}{c}{ Source } & F & Sig. \\
\hline Corrected Model & 8.044 & .000 \\
Intercept & 797.243 & .000 \\
Model & 5.027 & .028 \\
Kategori_KB & 12.578 & .001 \\
Model * Kategori_KB & 6.067 & .016 \\
\hline
\end{tabular}

Perbedaan kemampuan pemecahan masalah matematis siswa dengan pembelajaran model Problem Based Learning dan model Guided Discovery Learning

Hasil dari perhitungan anova dua jalur adalah $0,028<\alpha=0,05$ maka Ho ditolak. Hasil pengujian tersebut membuktikan bahwa terdapat perbedaan yang signifikan kemampuan pemecahan masalah matematis siswa model pembelajaran PBL dan model pembelajaran GDL. Berdasar pada rata-rata kemampuan pemecahan masalah matematis yang diperoleh siswa dengan pembelajaran model PBL dan model GDL berturut-turut 4,73 dan 4,03. Hal ini membuktikan bahwa rata-rata skor kemampuan pemecahan masalah matematis siswa yang diperoleh PBL lebih tinggi dari pada kemampuan pemecahan masalah matematis model pembelajaran GDL

Pengaruh interaksi model pembelajaran dan kemandirian belajar siswa terhadap kemampuan pemecahan masalah matematis siswa

Berdasar hasil analisis varians dua jalur pada Tabel 2. mengenai kemampuan pemecahan masalah matematis siswa antara 
model pembelajaran dan kemandirian belajar diperoleh nilai signifikansi $0,016<\alpha=$ 0,05 mengakibatkan ditolaknya $\mathrm{H}_{0}$. Hal ini menunjukkan adanya interaksi antara model pembelajaran dan kemandirian belajar.

Perbedaan kemampuan pemecahan masalah matematis siswa dengan pembelajaran model Problem Based Learning dan siswa dengan pembelajaran model Guided Discovery Learning pada kelompok siswa yang memiliki kemandirian belajar tinggi

Perbedaan kemampuan pemecahan masalah matematis siswa dengan pembelajaran model PBL dan model GDL pada siswa yang memiliki kemandirian belajar tinggi dilakukan dengan menggunakan uji-t. Hasil perhitungan uji-t pada kelompok siswa dengan kemandirian belajar tinggi dapat dilihat pada Tabel 3.

Berdasar pada hasil uji-t yang terdapat pada Tabel 3. dapat diketahui bahwa nilai probabilitas sig2-tailed yaitu $0,004<\alpha$ $=0,05$. Sehingga dapat disimpulkan bahwa terdapat perbedaan yang signifikan rata-rata skor kemampuan pemecahan masalah matematis antara siswa dengan pembelajaran model PBL dan siswa dengan model GDL, pada kelompok siswa yang memiliki kemandirian belajar tinggi.

Tabel 3. Hasil Uji-t Untuk Kemandirian Belajar Tinggi

\begin{tabular}{llccccc}
\hline & & \multicolumn{2}{c}{$\begin{array}{c}\text { Levene's Test for Equality } \\
\text { of Variances }\end{array}$} & \multicolumn{2}{c}{ t-test for Equality of Means } \\
\cline { 3 - 7 } & Equal variances assumed & 1.842 & Sig. & t & df & Sig. (2-tailed) \\
\cline { 2 - 7 } Nilai_KPM & Equal variances not assumed & & & 3.102 & 37 & .004 \\
\hline
\end{tabular}

Perbedaan kemampuan pemecahan masalah matematis siswa dengan pembelajaran model Problem Based Learning dan siswa dengan pembelajaran model Guided Discovery Learning pada kelompok siswa yang memiliki kemandirian belajar rendah
Perbedaan kemampuan pemecahan masalah matematis siswa dengan pembelajaran model PBL dan model GDL pada siswa yang memiliki kemandirian belajar tinggi dilakukan dengan menggunakan uji-t yang disajikan pada Tabel 4 .

Tabel 4. Hasil Uji-t Untuk Kemandirian Belajar Rendah

\begin{tabular}{llccccc}
\hline & & \multicolumn{2}{c}{$\begin{array}{c}\text { Levene's Test for } \\
\text { Equality of Variances }\end{array}$} & t-test for Equality of Means \\
\cline { 2 - 7 } & F & Sig. & t & df & Sig. (2-tailed) \\
\hline \multirow{2}{*}{ Nilai_KPM } & Equal variances assumed & 6.520 & .015 & -.170 & 37 & .866 \\
\cline { 2 - 7 } & Equal variances not assumed & & & -.172 & 31.468 & .865 \\
\hline
\end{tabular}

Pada Tabel 4, terlihat nilai sig2-tailed $0,866>\alpha=0,05$. Sehingga dapat disimpulkan bahwa tidak terdapat perbedaan yang signifikan rata-rata skor kemampuan pemecahan masalah pemecahan masalah matematis antara siswa dengan pembelajaran model PBL dan siswa dengan pembelajaran 
model GDL, pada kelompok siswa yang memiliki kemandirian belajar rendah.

\section{PEMBAHASAN}

Kemampuan pemecahan masalah matematis siswa dengan pembelajaran model PBL lebih tinggi dibandingkan dengan kemampuan pemecahan masalah matematis siswa dengan pembelajaran model GDL

Berdasarkan hasil pengujian diketahui bahwa pemberian perlakuan model PBL lebih efektif dalam meningkatkan kemampuan pemecahan masalah matematis siswa. Kemampuan pemecahan masalah membutuhkan penalaran dan strategi dalam membuktikan sebuah hipotesis ataupun masalah non rutin. Ketika siswa terbiasa memecahkan masalah non rutin atau terbiasa dalam membuktikan hipotesis maka siswa akan terbiasa pula dalam memecah-kan masalah. Uraian di atas senada dengan pendapat (Abidin, 2015) yang menyatakan kemampuan pemecahan masalah adalah upaya pelibatan diri dalam tugas atau masalah yang metode pengerjaannya belum diketahui sebelumnya.

Langkah-langkah dalam PBL mentuntun siswa dalam menumbuhkan sikap ilmiah dalam memecahkan dan menyelesaikan masalah. Pada langkah orientasi, siswa diharuskan untuk memahami dan menggunakan penalarannya dalam memahami masalah. Pada langkah mendiagnosis masalah, siswa yang telah memahami masalah kemudian mencari solusi yang tepat atas masalah yang diberikan. Kemudian mencari strategi yang tepat dalam menyelesaikan masalah. Pada langkah melaksanakan penyelidikan individu atau kelompok, siswa mencari pengetahuan atau informasi yang tepat dan menyaring semua pengetahuan yang relevan baik itu yang telah dimiliki atau pengetahun yang telah didapat untuk digunakan dalam memecahkan masalah. Sementara itu, langkah dalam GDL khususnya langkah eksplorasi dibawah bimbingan guru, siswa menemukan konsep melalui proses percobaan dan kesalahan (trial and errors) sehingga siswa membangun pengetahuan mereka sendiri dalam menemukan solusi dalam memecahkan masalah. Sependapat dengan pendapat (Illahi, 2012) yang menyatakan bahwa salah satu tujuan GDL adalah belajar memecahkan masalah.

Di lain hal, GDL adalah sebuah model pembelajaran dengan menggunakan pendekatan induktif atau penyelidikan untuk belajar sehingga materi tidak diberikan dalam bentuk final yang menyebabkan siswa diharuskan berpikir induktif untuk memahami konsep. Selain itu, proses pembel-ajaran GDL memungkinkan siswa menemukan konsep melalui serangkaian pengalamanpengalaman yang konkret. Namun, pada GDL, siswa mengikuti prosedur yang diberikan oleh guru dalam menemukan konsep sehingga siswa tidak dapat mengembangkan kemampuan berpikir mereka dalam bernalar. Tetapi, PBL mempunyai kelebihan yaitu dengan pemberian masalah di awal pembelajaran, siswa akan memahami dan mencari solusi atas masalah yang diberikan dengan cara mereka sendiri sehingga kemampuan pemecahan masalah yang dimiliki siswa berkembang.

\section{Terdapat interaksi model pembelajaran dan kemandirian belajar siswa terhadap kemampuan pemecahan masalah mate- matis siswa}

Hasil dari pengujian hipotesis kedua ditemukan bahwa terdapat interaksi antara 
model pembelajaran dan kemandirian belajar siswa terhadap kemampuan pemecahan masalah matematis. Adanya interaksi berarti model pembelajaran dan kemandirian belajar secara bersama memberikan pengaruh yang signifikan terhadap kemampuan pemecahan masalah matematis siswa. Dengan kata lain, model pembelajaran memberikan pengaruh yang berbeda terhadap kemampuan pemecahan masalah matematis jika diterapkan pada siswa yang memiliki kemandirian belajar yang berbeda.

Model pembelajaran PBL merupakan model pembelajaran yang keberhasilannya bergantung pada diri siswa sendiri. Sedangkan guru hanya berperan sebagai fasilitator. Siswa yang memiliki kemandirian belajar tinggi akan berinisisatif dalam mencari sumber-sumber yang relevan serta berusaha menyelesaikan tugas-tugas yang menantang yang diberikan oleh guru. hal ini didukung oleh pernyataan (Metallidou \& Vlachou, 2010) yang menyatakan bahwa siswa yang mempunyai kemandirian belajar tinggi akan dapat menyelesaikan tugas-tugas yang diberikan dengan baik. Berdasar pada uraian di atas dapat disimpulkan bahwa kelompok siswa yang memiliki kemandirian belajar tinggi, pemberian perlakuan pembelajaran model PBL akan lebih efektif dibanding dengan model pembelajaran GDL.

Siswa dengan kemandirian belajar rendah, cenderung tidak memiliki inisiatif, tidak memiliki kepercayaan diri yang tinggi dan akan memerlukan usaha yang keras dalam menemukan solusi untuk memecahkan masalah. Namun, dengan model GDL khususnya pada langkah eksplorasi dibawah bimbingan guru, guru akan selalu memberi masukan, membimbing serta memantau kemajuan siswanya dalam mengkonstruksi cara belajar siswa sendiri tanpa terjadi kesalahan.
Sehingga siswa yang memiliki kemandirian belajar rendah akan aktif dalam mengikuti kegiatan belajar mengajar sehingga dapat memahami materi dengan baik dan mendalam.

\section{Kemampuan pemecahan masalah mate- matis siswa dengan pembelajaran model PBL lebih tinggi daripada siswa dengan pembelajaran model pembelajaran GDL pada kelompok siswa yang memiliki ke- mandirian belajar tinggi}

Siswa dengan kemandirian belajar tinggi, ditemukan bahwa terdapat perbedaan signifikan antara hasil kemampuan pemecahan masalah matematis siswa dengan pembelajaran model PBL dan siswa dengan pembelajaran model GDL. Hal ini ditunjukkan dengan rata-rata hasil kemampuan pemecahan masalah matematis siswa yang menggunakan model pembelajaran PBL lebih tinggi dari rata-rata hasil kemampuan pemecahan masalah matematis siswa yang menggunakan model pembelajaran GDL.

Siswa yang memiliki kemandirian belajar tinggi akan selalu berusaha menyelesaikan permasalahan yang diberikan dengan cara dan strategi mereka sendiri serta akan selalu merasa terantang untuk menyelesaikan soal-soal yang sulit (soal non rutin). Ketika siswa terbiasa dalam memecahkan soal-soal pemecahan masalah yang non rutin maka tanpa siswa sadari kemampuan mereka dalam memecahkan masalah ber-kembang. Akan sangat berbeda jika siswa kemandirian belajar tinggi diberi perlakuan model pembelajaran GDL.

Model pembelajaran GDL adalah suatu model pembelajaran yang dirancang sedemikian sehingga siswa dapat menemukan konsep-konsep melalui proses mentalnya 
sendiri. Artinya GDL dirancang untuk membuat siswa aktif dalam menemukan konsep. Senada dengan pendapat Lestari dan (Lestari \& Yudhanegara, 2015) yang mengatakan GDL adalah suatu model pembelajaran yang dirancang sedemikian sehingga siswa dapat menemukan konsep-konsep dan prinsipprinsip melalui proses mentalnya sendiri. Namun pada langkah eksplorasi dibawah bimbingan guru dengan prosedur yang diberikan oleh guru sehingga siswa dengan kemandirian belajar tinggi tidak dapat mengembangkan kemampuan mereka dalam bernalar dan memecahkan masalah. Hal ini mengakibatkan kemampuan pemecahan masalah matematis siswa yang memiliki kemandirian belajar tinggi tidak berkembang.

Tidak terdapat perbedaan yang signifikan antara kemampuan pemecahan masalah matematis siswa dengan pembelajaran model PBL dengan siswa dengan pembelajaran model pembelajaran GDL pada kelompok siswa yang memiliki kemandirian belajar rendah

Berdasarkan hipotesis penelitian bahwa siswa dengan kemandirian belajar rendah, kemampuan pemecahan masalah matematis siswa dengan pembelajaran model PBL lebih rendah dari siswa dengan pembel-ajaran model GDL. Namun hasil dari uji statistik berbeda. Uji statistik menunjukkan bahwa siswa dengan kemandirian belajar rendah, kemampuan pemecahan masalah matematis siswa dengan pembelajaran model PBL tidak terdapat perbedaan yang signi-fikan dengan siswa dengan pembelajaran model pembelajaran GDL.

Guru mempunyai tujuan yang tinggi terhadap kemampuan pemecahan masalah matematis siswa. Hal ini membuat penerap- an model PBL dan model GDL dilakukan dengan cara siswa berkelompok. Guru membagi kelompok terdiri dari siswa dengan kemandirian belajar yang heterogen dan siswa yang memiliki kemandirian tinggi ditunjuk sebagai ketua. Pada akhir pembelajaran kelompok siswa yang mempresentasikan hasil diskusi dipilih secara acak. Hal ini dimaksudkan agar semua siswa bersungguh-sungguh dalam berdiskusi kelompok.

Model pembelajaran GDL diawali dengan pemberian masalah berupa LAS yang menuntun siswa untuk menemukan konsep dengan bimbingan dan pantauan guru. Siswa dengan kemandirian belajar rendah memiliki inisiatif, percaya diri, dan tanggung jawab yang rendah. Senada dengan pendapat Nurhayati (2011) kemandirian belajar merupakan suatu keadaan dimana siswa memiliki hasrat siswa untuk bersaing sehingga siswa memiliki inisiatif, percaya diri dan bertanggung jawab terhadap apa yang dilakukannya. Hal ini menyebabkan dalam model GDL siswa dipaksa untuk mengkonstruksi pemahaman mereka sendiri namun dengan pantauan dan bimbingan guru serta dengan bimbingan teman yang memiliki kemandirian belajar tinggi dalam kelompoknya. Hal inilah yang membuat siswa dengan kemandirian belajar rendah sangat bergantung pada bimbingan guru dan bimbingan teman dalam kelompoknya. Siswa dengan kemandirian belajar rendah hanya mendengarkan ide-ide dari siswa yang memiliki kemandirian belajar tinggi. Oleh karena itu, ketika siswa dengan kemandiri-an belajar rendah diberikan permasalahan yang harus dikerjakan sendiri tidak berke-lompok siswa akan merasa kebingungan dan merasa kurang percaya diri dalam mema-hami dan memecahkan masalah dengan baik sehingga 
berakibat pada kemampuan peme-cahan masalah matematis mereka rendah.

Model PBL, diawali dengan pengajuan masalah dan dibutuhkan kemampuan berpikir tingkat tinggi untuk menyelesaikannya. Hal ini mengakibatkan keberhasilan model pembelajaran PBL bergantung pada diri siswa sendiri. Metallidou \& Vlachou, (2010) yang menyatakan bahwa siswa yang mempunyai kemandirian belajar tinggi akan dapat menyelesaikan tugas-tugas yang diberikan dengan baik. Ketika berkelompok untuk menyelesaikan masalah yang diberikan guru berupa LAS, siswa dengan kemandirian belajar tinggi akan selalu mendominasi dalam memecahkan masalah dengan tingkat kesukaran yang lebih tinggi. Sedangkan siswa yang memiliki kemandirian belajar rendah mengerjakan soal yang tingkat kesukarannya lebih mudah. Setelah itu, terjadilah diskusi hasil LAS yang telah dikerjakan masing-masing. Ketika diskusi, siswa yang memiliki kemandirian belajar rendah selalu mendengarkan penjelasan siswa yang memiliki kemandirian tinggi dalam memecahkan masalah/soal yang tingkat kesukarannya tinggi. Kegiatan tutor sebaya sangat mempengaruhi kemampuan pemecahan masalah matematis siswa Hal ini mengakibatkan siswa yang memliki kemandirian belajar rendah tidak terbiasa dalam memecahkan masalah dengan tingkat kesukaran yang tinggi dan selalu bergantung pada siswa dengan kemandirian belajar tinggi serta tidak memiliki inisiatif untuk mencari bagaimana cara untuk memecahkan masalah yang diberikan sehingga mereka tidak memiliki pengetahuan dan pengalaman yang dapat digunakan untuk memecahkan masalah yang sama dilain waktu. Hal ini meng-akibatkan kemampuan pemecahan masalah matematis mereka tidak berkembang.
Berdasarkan uraian di atas kesamaan dari kedua model pada siswa yang memiliki ke-mandirian belajar rendah adalah siswa dengan kemandirian belajar rendah bergantung pada siswa dengan kemandirian belajar tinggi. Pada model GDL khususnya pada tahap eksplorasi dibawah bimbingan guru, siswa yang mengalami kesulitan pasti akan bertanya pada siswa dengan kemandirian belajar tinggi dan guru. pada model GDL siswa pasti akan bertanya pada siswa dengan kemandirian belajar tinggi pada saat mengkerjakan LAS yang diberikan oleh guru. hal ini mengakibatkan kemampuan pemecahan masalah mereka tidak berkembang. Sehingga dapat disimpulkan bahwa tidak terdapat perbedaan yang signifikan antara kemampuan pemecahan masalah matematis antara siswa dengan pembelajaran model PBL dan kemampuan pemecahan masalah matematis siswa dengan pembelajaran model GDL pada kelompok siswa yang memiliki keman-dirian belajar rendah. Hasil penelitian yang diperoleh senada dengan penelitian yang dilakukan oleh F. Nurhayati (2016). Hasil penelitiannya mengatakan bahwa model PBL dan model GDL dengan pendekatan Problem Posing efektif dalam meningkatkan prestasi belajar, kemampuan pemecahan masalah matematis dan minat belajar siswa. Namun, tidak terdapat perbedaan keefek-tifan antara kedua model dalam mening-katkan prestasi belajar, kemampuan pemecahan masalah matematis dan minat belajar.

\section{SIMPULAN}

Simpulan dapat bersifat generalisasi temuan sesuai permasalahan penelitian, dapat pula berupa rekomendatif untuk langkah selanjutnya. 


\section{DAFTAR PUSTAKA}

Abidin, Z. (2015). Intuisi Dalam Pembelajaran Matematika. Jakarta: Lentera Ilmu Cendekia.

Arends, R. I. (2008). Learning To Teach (buku dua). Yogyakarta: Pustaka Pelajar.

Casad, B. J., State, C., Jawaharlal, M., \& State, C. (2012). Learning through guided discovery: An engaging approach to K-12 STEM education. In ASEE Annual Conference and Exposition, Conference Proceedings. Retrieved from http://www.scopus.com/inward/record.url? eid=2-s2.084864996335\&partnerID $=40 \&$ md5 $=19 \mathrm{c} 20$ cf6aa0e56fa48ea05b649422cd7

Hanifah. (2015). Penerapan Pembelajaran Model Elicting Activities (MEA) dengan Pendekatan Saintifik Untuk Meningkatkan kemampuan Representasi dan Pemecahan Masalah matematis Siswa. Universitas Pendidikan Indonesia.

Illahi, M. T. (2012). Pembelajaran Discovery \& Mental Vocational Skill. Yogyakarta: Diva Press.

Lestari, E. K., \& Yudhanegara, M. R. (2015). Penelitian Pendidikan Matematika. Bandung: PT. Refika Aditama.

Metallidou, P., \& Vlachou, A. (2010). Paradojas y dilemas en el proceso de inclusi??n educativa en Espa??a. Psychology in the Schools, 47(8), 153-178.

https://doi.org/10.1002/pits
Naga, D. S. (1992). Pengantar Teori Sekor Pada Pengukuran Pendidikan. Jakarta: Gunadarma.

Nurhayati, E. (2011). Psikologi Pendidikan Inovatif. Yogyakarta: Pustaka Pelajar.

Nurhayati, F. (2016). Perbandingan Keefektifan Model Problem Based Learning dan Model Discovery Learning dengan Pendekatan Problem Posing pada Pembelajaran Geometri Bangun Datar ditinjau dari Prestasi Belajar Matematika, Kemampuan Pemecahan Masalah, dan Minat Belajar Siswa SMP. Universitas Negeri Yogyakarta.

Padmavathy, R. D., \& Mareesh.K. (2013). Effectiveness of Problem Based Learning In Mathematics. International Multidisciplinary E-Journal, 2(I), 45-51.

Perels, F., Dignath, C., \& Schmitz, B. (2009). Is it possible to improve mathematical achievement by means of self-regulation strategies? Evaluation of an intervention in regular math classes. European Journal of Psychology of Education, 24(1), 17-31. https://doi.org/10.1007/BF03173472

Yonandi. (2011). Meningkatkan Kemampuan Komunikasi dan Pemecahan Masalah Matematik Melalui Pembelajaran Kontekstual Berbantuan Komputer Pada Siswa. Universitas Pendidikan Indonesia. 